\title{
Failure Investigation: Analysis Procedure and Some Notable Aircraft and Aeroengine Service Failures
}

\author{
Ivan Lazarević ${ }^{1)}$ \\ Zoran Petrović ${ }^{1)}$
}

\begin{abstract}
Failure of an aircraft structural component can have catastrophic consequences, with a resultant loss of life and of the aircraft. The investigation of defects and failures in aircraft structures is, thus, of the vital importance in preventing further incidents. This review discusses the common failure modes observed in aircraft structures, with examples drawn from case histories. A review has given three notable aircraft and aeroengine service failures investigated by the National Aerospace Laboratory NLR in the Netherlands. All three failures were initiated by a corrosion.
\end{abstract}

Key words: aircraft, helicopter, propeller, rotor of the helicopter, corrosion, failure, analysis of processes, fractography

\section{Introduction}

$\mathrm{F}$ AILURE of an aircraft structural component can have catastrophic consequences, with a resultant loss of life and of the aircraft. The investigation of defects and failures in aircraft structures is, thus, of the vital importance in preventing further incidents. This review discusses the common failure modes observed in aircraft structures, with examples drawn from case histories. The review will also outline the investigative procedures employed in examination of the failed components.

Any failure occurring on the structural materials applied on air platforms needs to be studied in order to avoid other accidents which are going to happen on an aircraft of the same fleet. Though, the economic and safety issues are driving forces to develop a more efficient failure analysis and investigations [1].

Table 1. Frequency of the failure mechanisms [1]

\begin{tabular}{|c|c|c|}
\hline \multirow{2}{*}{} & \multicolumn{2}{|c|}{ Percentage of Failures } \\
\cline { 2 - 3 } & $\begin{array}{c}\text { Engineering } \\
\text { Components }\end{array}$ & $\begin{array}{c}\text { Aircraft } \\
\text { Components }\end{array}$ \\
\hline \hline Corrosion & 29 & 16 \\
\hline Fatigue & 25 & 55 \\
\hline Brittle fracture & 16 & - \\
\hline Overload & 11 & 14 \\
\hline High temperature corrosion & 7 & 2 \\
\hline SCC/Corrosion fatigue/HE & 6 & - \\
\hline Creep & 3 & 6 \\
\hline Wear/abrasion/erosion & 3 & \\
\hline
\end{tabular}

\section{The objective of the failure analysis}

The Failure Investigation is undertaken to determine the cause of a failure, and if possible, to identify corrective actions that should be initiated to prevent similar failures [2]. The failure analysis is a powerful tool for solving engineering problems and can provide significant savings in the development of the components.

\section{General Stages of an Analysis}

The nature of the failure being investigated determines what steps and processes must be employed. The following is a brief description of the typical stages of the Failure Investigation. These are guidelines to be considered by the investigator; however, not every stage may be utilized [2]



Figure 1. Failure Investigation Process Flow

\footnotetext{
1) 204. Air Force Brigade RS, Pukovnika Milenka Pavlovića bb, 11273 Batajnica, SERBIA

Correspondence to: Ivan Lazarević; e-mail: ivan.lazarevic303@gmail.com
} 


\section{Collection of preliminary data}

Initially, the Failure Investigation should be directed towards gathering as much information relating to the failure insofar as to reconstructing its sequence of events.

This may involve obtaining materials specifications, drawings, and records as to the manufacturing, processing, and service history of the failed component or structure. Also, data on the parameters of the flight could be of a great benefit to the investigation [2].

\section{Laboratory Investigations}

\subsection{Photographic Records}

It is important for the investigator to maintain a photographic record of the failed component (e.g. macroscopic, fractographs, micrographs, etc.) throughout the analysis to detail the characteristics of the failure [2].

\subsection{Selection of the samples}

It is critical that the investigator selects the correct components that accurately depict the failure. Sometimes, this may involve seeking other evidence of damage beyond the apparent failed component [2].

\subsection{Preliminary examination of the damaged compo- nents}

Before cleaning, the condition of the damaged components should be described in the record "as received". This is useful in determining the sequence of events leading to the failure. A thorough visual inspection and detailed record keeping are very important for the success of the investigation.

Visual inspection should be performed initially unaided and subsequently with the photographic microscopes.

For the fractured components, it is essential to document the entire component and then relate the fracture to the entire component [2].

\subsection{Sample handling}

\subsubsection{Conservation (preservation)}

Fracture surfaces are prone to mechanical and / or chemical damage, so the proper selection, cleaning and conservation of the fracture surface is very important to prevent the destruction or contamination of the same.

The fracture surfaces should never be touched by fingers or be fitted together with the sections of a part. They should also be covered with a cloth or cotton during transport and stored in containers or rooms where moisture is removed in order to preserve the existing state of corrosion [2].

\subsubsection{Cleaning}

Fracture surface should be cleaned when necessary, such as, for example, preparation of the fracture surface for an electron microscopy observation. Applied techniques are dry cleaning with compressed air, ultrasonic cleaning with solvents or mild detergent and removing the plastic isolation.

When working with plastic materials avoid organic solvents [2].

\subsubsection{Cutting (Sectioning)}

Due to the size limitations of the equipment for testing and assessment, such as hardness testers and optical microscopes, it is sometimes necessary to allocate a part of the fracture surface containing the damaged components. It is very important to keep the fracture surface when cutting, using coolant or secondary coatings [2].

\subsubsection{Cracks opening}

In the event that the primary cracks are not developed until the final fracture, they must be open.

On the other hand, if the primary crack is damaged or corroded so that the fracture surface is damaged, it is necessary to open the secondary cracks for testing and study. These cracks can provide more information since they are less damaged or corroded.

The proposal is to open the cracks such that the two fracture surfaces move opposite to each other, perpendicular to the plane of the fracture (crack). Sometimes, the use of different mechanisms of the fracture can be used to differentiate primary from secondary cracks [2].

\subsection{Non-Destructive Testing}

Non-destructive testing can be useful in detecting surface cracks and discontinuities in the damaged components $[2,3]$.

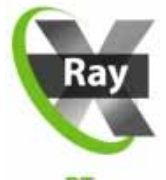

RT

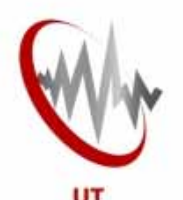

UT



LPT



MAGNETIC Test
Figure 2. Some of the commonly used techniques of non-destructive testing [3]

Magnetic particle testing, eddy current testing, ultrasonic testing, liquid-penetrant inspection and radiography are some of the most commonly used techniques of the nondestructive testing.

\subsection{Mechanical Testing}

Mechanical testing helps if the component is not in accordance with the specification or in assessing the impact of surface conditions on the mechanical properties $[2,3]$.



Tensile Test

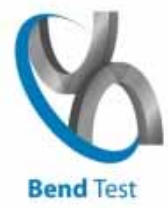

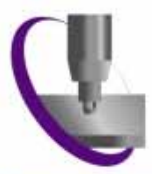

HARDNESS Test
Figure 3. Some of the commonly used techniques of mechanical testing [3]

\subsubsection{Hardness}

Hardness testing can be used to assist in an assessment of the heat treatment.

\subsubsection{Tensile strength and toughness}

These tests should be performed only if there is sufficient material for the preparation of the samples for testing.

\subsubsection{Dynamo-mechanical analysis}

These tests should be done on plastic materials and polymer composites only if there is sufficient material for the preparation of the samples for testing. 


\subsection{Chemical and elemental analysis}

In a Failure Investigation, a routine analysis is recommended to confirm that the material is one that was listed in a specification. Minor deviations in compositions are unlikely responsible for failure.

It is useful to identify and determine the concentrations of elements in the alloy, sediments, samples of fluid from the environment, lubricants, etc.

Various analytical techniques can be used in a failure investigation: emission spectroscopy, atomic absorption spectroscopy, inductively coupled plasma atomic emission spectroscopy, classical wet analytical chemistry, and spot tests. Surface integral elements can be identified by using the energy-dispersive and wavelength dispersive $\mathrm{x}$-ray spectrometries (analytical techniques used for elemental analysis or chemical characterization of the sample).

Polymeric materials must be tested for their chemical nature and the thermodynamic and kinetic parameters, by means of infrared spectroscopy, gas chromatography (method of chemical analysis in which the sample is heated to decomposition of the molecules which are separated by gas chromatography and detected by mass spectrometry) and thermal analysis [2].

\subsection{Fractographic examination}

Fractography is the interpretation of the features observed on the fracture surfaces and, although it is simple in many cases, it can prove to be fairly difficult in practice. This is particularly the case on high strength quenched and tempered steels, or in alloys (such as cast irons and pearlitic steels) where the microstructure affects the crack path [4].

Fracture surface is a source of information regarding the cause of the fracture. It contains the evidence about the material disadvantages, the impact of the environment, as well as the use of force.

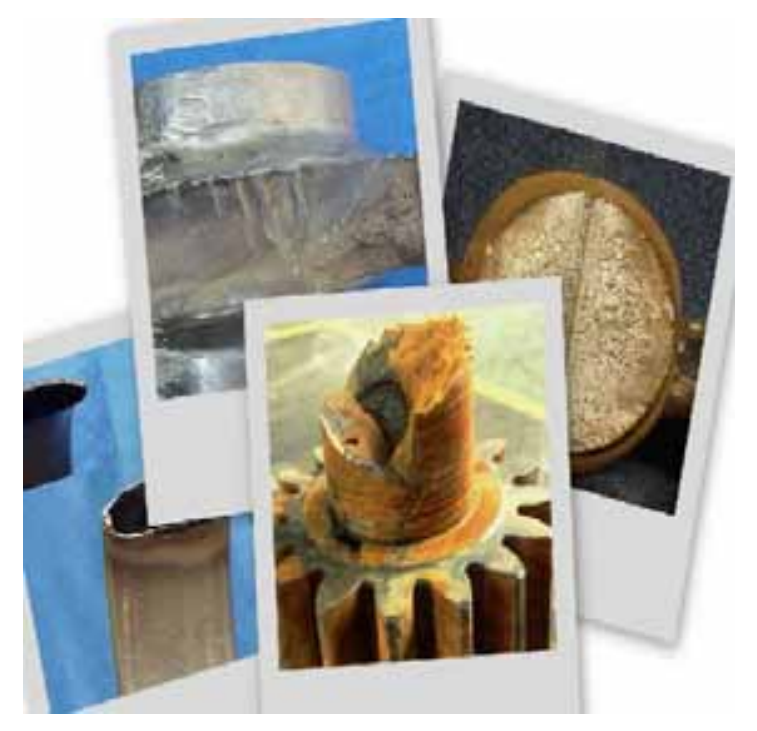

Figure 4. Fractographic records [4]

\subsubsection{Macroscopic Examination}

The detailed examination of the fracture surfaces at low magnifications (ranging from 1 to 100 times) may be done with the unaided eye, a hand lens, or a low-power optical microscope. The information obtained can give an indication of the stress system that produced the failure, the direction of the crack growth and therefore the origin of the failure [2].

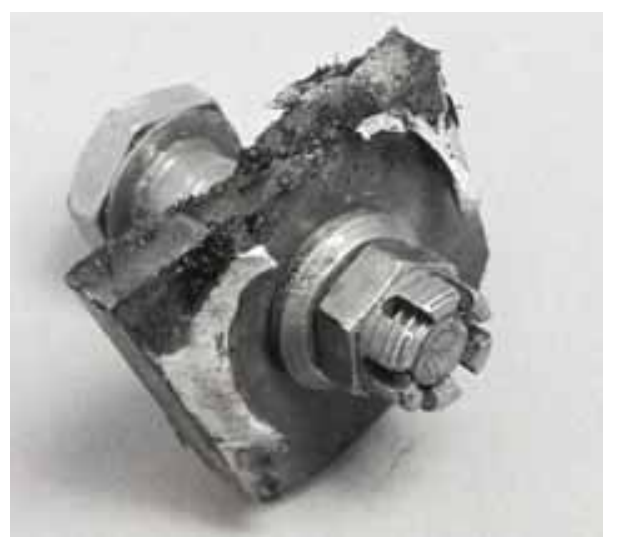

Figure 5. Details of the lug fracture, which was close to welds joining the lug into the airframe. (In October1990 a Aérospatiale Alouette III helicopter crashed in the Veluwe). [6]

\subsubsection{Microscopic Examination}

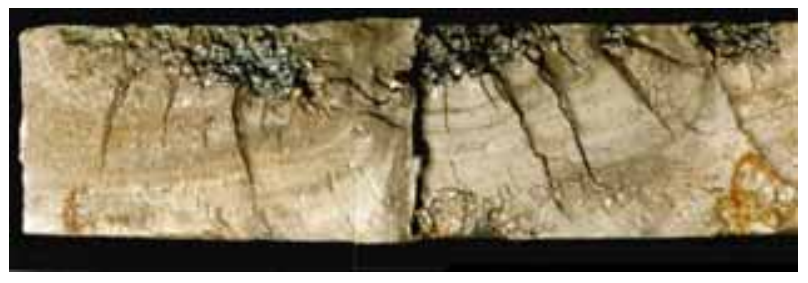

Figure 6. Details of the tail lug fracture, showing intergranular cracking followed by the fatigue. The failure occurred by the fatigue initiating from intergranular cracks on the upper side. The intergranular cracks were heattinted. (In October1990 a Aérospatiale Alouette III helicopter crashed in the Veluwe). [6]

Microscopic examination of the fractured surfaces can be achieved with the optical (light) and scanning electron microscopies. However, interpretation of the fractographic requires a practice and an understanding of the fracture mechanisms.

\subsubsection{Analysis of the microstructure}

Metallographic examination of the polished and polished-and-etched sections by an optical microscope and an electro-optical technique is a vital part of the failure analysis and should be implemented as a routine procedure.

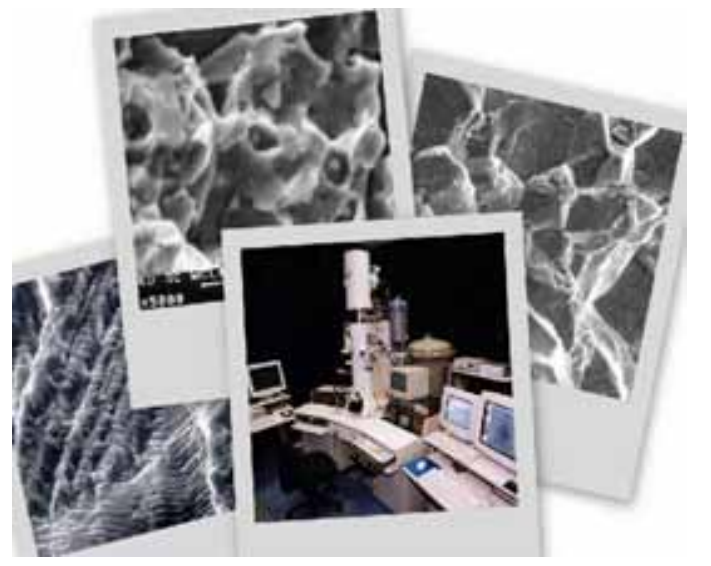

Figure 7. Microscopic records

Metallurgical imperfections or impurities and microstructural segregation in metals, such as voids (holes) in polymer composites can be detected and analyzed by a microscopic examination [2]. 


\subsection{Defining the Types of Fracture}

Examination of the failure region, the fracture surfaces, and metallographic sections is necessary to identify the fracture type.

Fractures are usually classified according to the mechanism of growth: ductile, brittle, intergranular, transgranular, and fatigue.

These mechanisms can be correlated with different types of fracture, such as failures incurred as the consequence effects of the environment (stress-corrosion cracking, melting, liquid-plastic deterioration, liquid-metal embrittlement, hydrogen embrittlement and creep) and fractures incurred as a consequence of stress (overload, wear, impact load) [2].

\subsection{Application of Simulation Tools}

Finite Element Analysis (FEA) may be worthwhile in assessing how stresses act on a failed part, by calculating the stress concentration factor $(\mathrm{Kt})$ and residual fatigue life, either in presence or in absence of an existing crack or defect.

\subsection{Application of the fracture mechanics theories}

Fracture mechanics studies the formation of cracks, its development and expansion of the fracture. It includes a part of the science that relates to the final stage of the process of deformation under load.
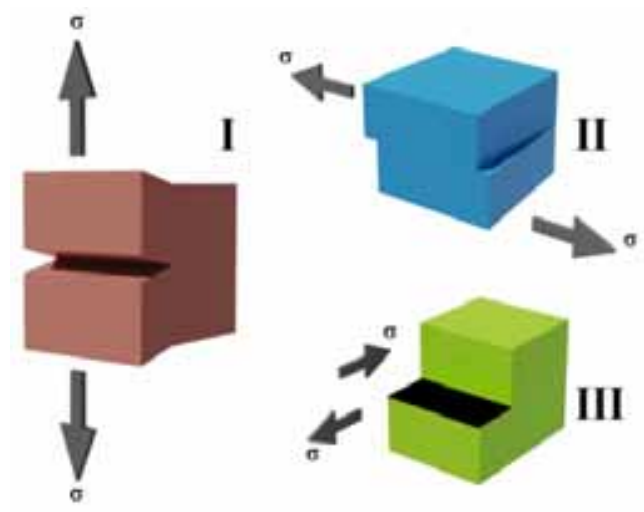

Figure 8. Basic shapes of crack development and shaping of the fracture surface [5]

\subsection{Simulated Service Testing}

It may be necessary to conduct tests that attempt to simulate the conditions under which the failure is believed to have occurred. Most of the metallurgical phenomena involved in failures can be satisfactorily reproduced on a laboratory scale, and the information derived from such experiments can be helpful to the investigator provided the limitations of the tests are fully understood. Furthermore, the simulated testing of the effects of certain selected variables encountered in service may be helpful in planning corrective action that will avoid similar failure or, at least, extend service life.

\section{Final report}

\section{Report Index}

- Object (It will clearly indicate a vehicle and a part gone under the investigation.)

- Introduction (Presents the Statement of Work as tasked by the customer and the reason the customer requested the tests. It also identifies the customer. The introduction should also include a "background" discussion, which will clearly relate the sample history.)

- Selection of the failed parts

- Preliminary examinations

- Fractographic examinations

- Chemical analysis

- Mechanical analysis

- NDT (optional)

- Application of the Simulation Tools (optional)

- Simulated-Service Testing (optional)

- Discussion on the experimental results (Discuss the significance of the experimental results. Describe how the results apply to the statement of work and how they led to conclusions.)

- Discussion on the experimental results

- Application of the Fracture Mechanics Theories (optional)

- Determination of the Fracture Types

- Individuation of the failure cause and chronological events

- Conclusions

- Recommendations (optional)

- References (optional) and

- Acknowledgements (optional)

\section{Aircraft service failures investigated by the Na- tional Aerospace Laboratory NLR}

A review is given of some notable aircraft and aeroengine service failures investigated by the National Aerospace Laboratory NLR in the Netherlands. The selected failures are: the rotor blade of helicopter Sikorsky S-61N (1974), the propeller blade of Air Tractor AT-301 (1987) and the lever arm pin of General Dynamics F-16 / Pratt \& Whitney F100-PW-220 RCVV (1992). All three failures were initiated by a corrosion.

\section{The rotor blade of the Sikorsky S-61N helicopter (1974)}

In May 1974 a Sikorsky S-61N helicopter crashed into the North Sea with the loss of six lives. Fig.9 shows the aircraft type and Fig.10 shows the crashed helicopter during the recovery. All the main rotor blades were broken, but the blade 3 was exceptional in showing little deformation at the fracture location (indicated in Fig.10) [6,7].

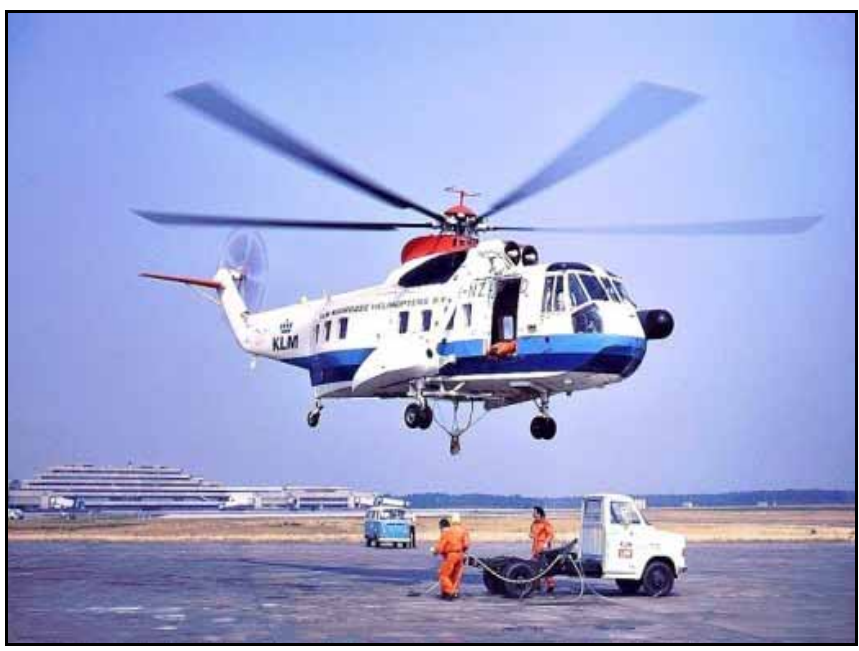

Figure 9. Sikorsky S-61N PH-NZD [6] 




Figure 10. Recovery of the Sikorsky S-61N PH-NZD from the North Sea [6]

Fig.11a shows the recovered fracture surface of the blade 3 , consisting of a hollow spar made from aluminium alloy AA6061-T6. The spar had been adhesively bonded to aluminium face in form of the ribbed aluminum pocket, as shown in Fig. 11b. The first phase in the failure sequence determined from the fractographic analysis was a highcycle fatigue initiating from the corrosion pits on the spar lower surface under the bonded area (indicated by the red arrow in Fig.11b) [6,7].

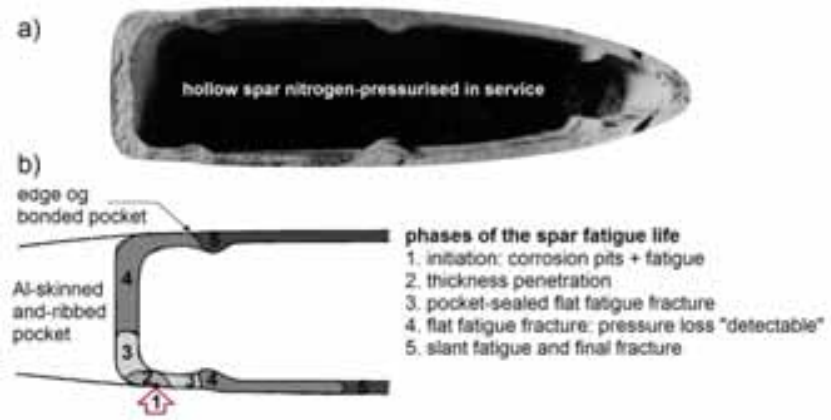

Figure 11. Recovered blade spar fracture surface and phases of the fatigue life [6]

\section{The propeller blade of Air Tractor AT-301 (1987)}

In June 1987 an Air Tractor AT-301 fitted with a twobladed propeller experienced loss of a propeller tip in flight. The pilot managed to switch the engine off and landed safely.

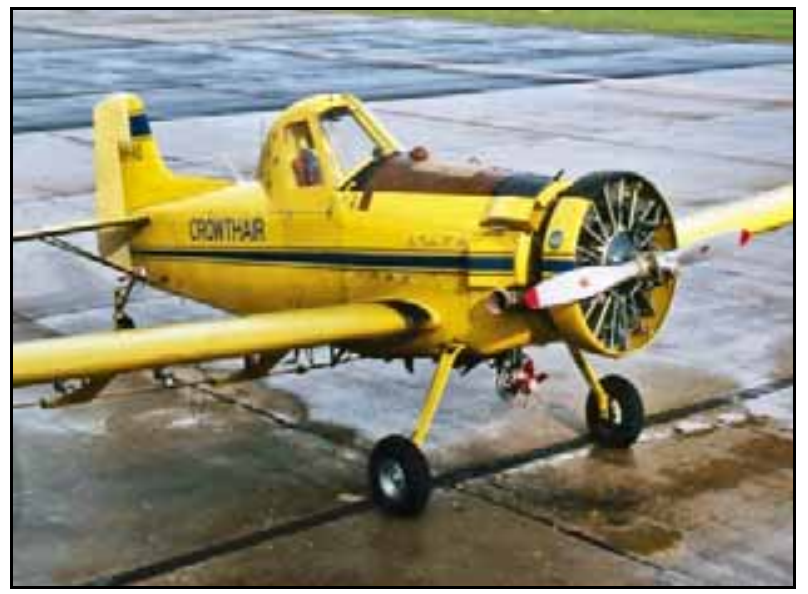

Figure 12. Air Tractor AT-301 (with a two-bladed propeller) [6]
Figure 12 shows the Air Tractor AT-301 aircraft at the time of the accident with a two-bladed propeller, while Figure 13 shows the same plane a year later, but this time with a three-bladed propeller $[6,8]$.

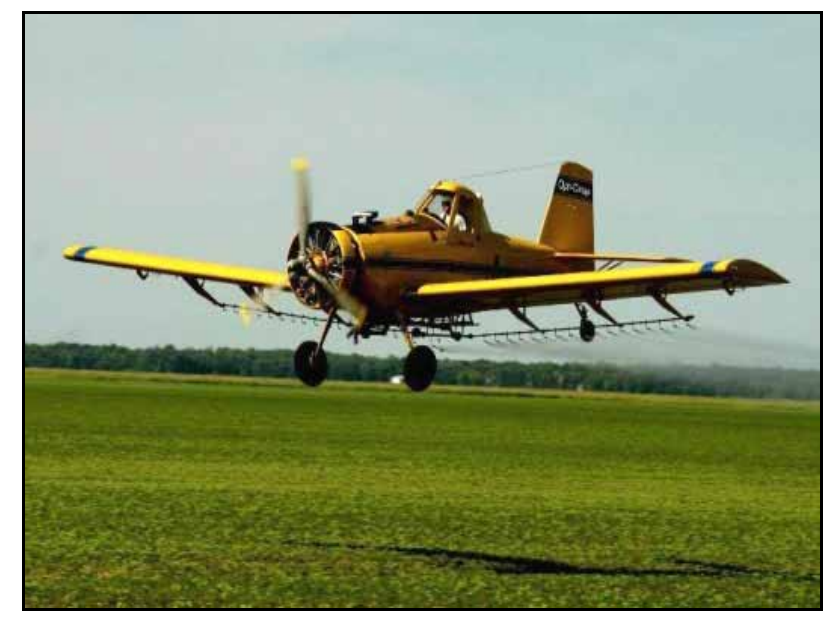

Figure 13. Air Tractor AT-301 (with a three-bladed propeller), about one year after the incident [6]

Fig.14 shows the broken propeller blade and a detail of its fracture surface. The propeller was manufactured by Pacific Propellers Inc., under the license to Hamilton Standard, and consisted of an aluminium alloy AA2025-T6 forging that had been chromic acid anodised. Despite the anodized surface, the propeller showed pitting and exfoliation corrosion. The corrosion was most probably due to attack and penetration of the anodised layer by deposits, which included sea salt. The broken blade failed by highcycle fatigue initiating from a $0.1 \mathrm{~mm}$ deep $\times 0.3 \mathrm{~mm}$ long corrosion pit on the convex surface $[6,8]$.

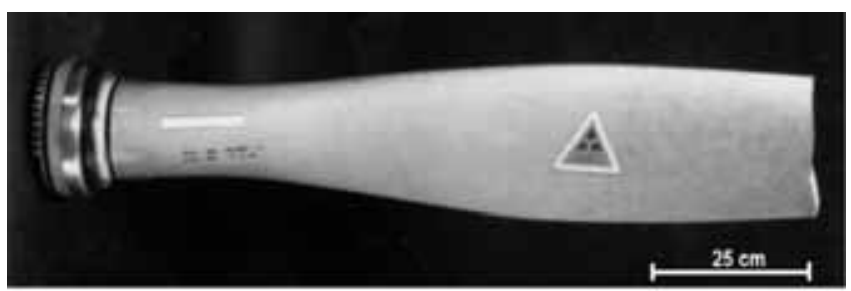

initiation: corrosion pit + fatigue

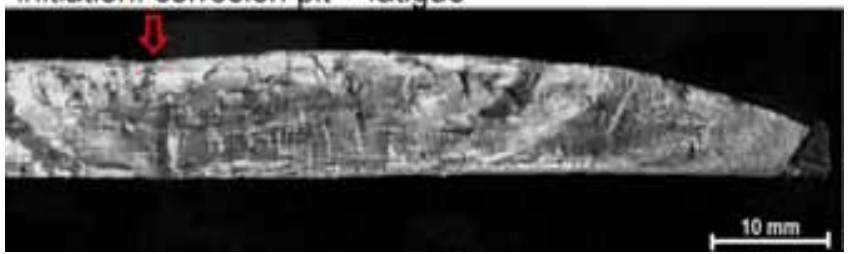

Figure 14. Broken propeller blade and a detail of the fracture surface [6]

\section{Causes of failure}

Propeller cleaning: The operator neglected to follow the manufacturer's recommendation to wash and oil the propeller blades after the last flight of the day.

Operating environment: The aircraft was used for crop spraying near the Dutch coast. This resulted in aggressive deposits on the propeller.

\section{The lever arm pin of the General Dynamics F-16 / Pratt \& Whitney F100-PW-220 RCVV (1992).}

In February 1992 a General Dynamics F-16 crashed between housing blocks in the city of Hengelo, without a loss of life. The crash was caused by an engine failure. 


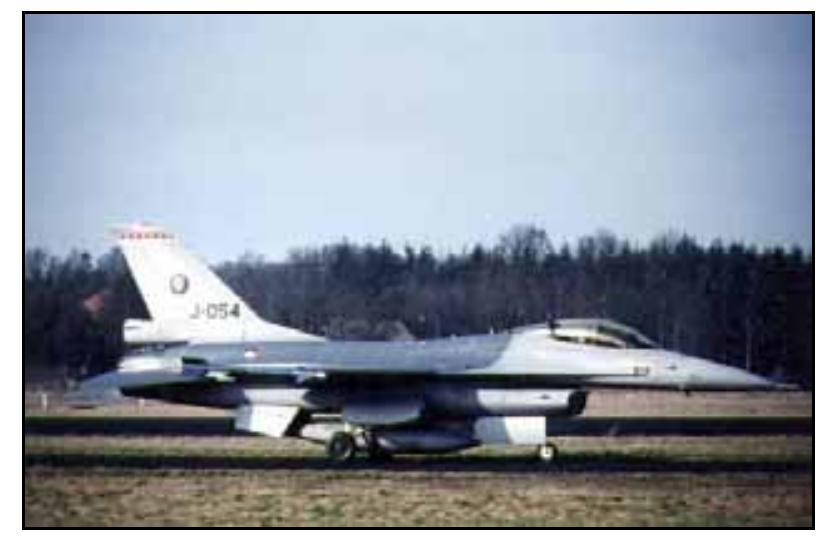

Figure 15. General Dynamics F-16 J-054

Figure 15 shows the General Dynamics F-16, while Figure 16 shows the crash site, including the remains of the Pratt \& Whitney F100-PW-220 engine. Fig.17 indicates the location of the engine failure, which was due to a fracture of a pin attached to a Rear Compressor Variable Vane (RCVV) lever arm [6,9].

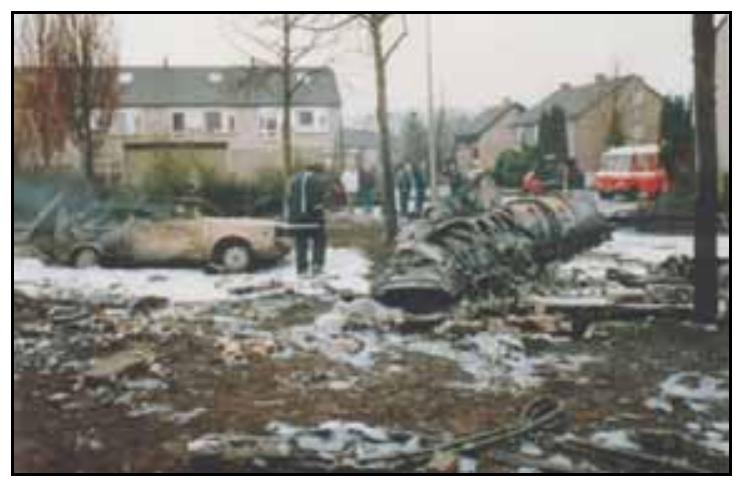

Figure 16. Crash site of F-16 J-054 and an indication of the engine [6]

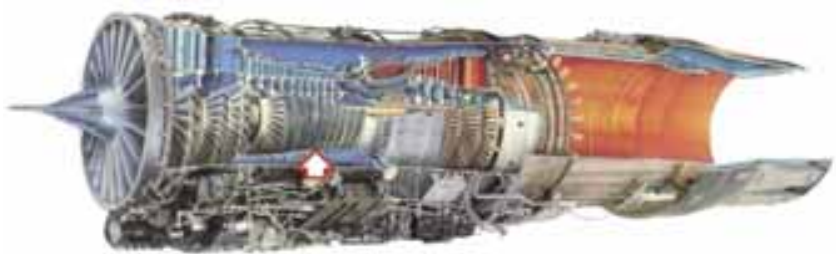

Figure 17. F100-PW-220 engine failure location: RCVV lever arm assembly [6]

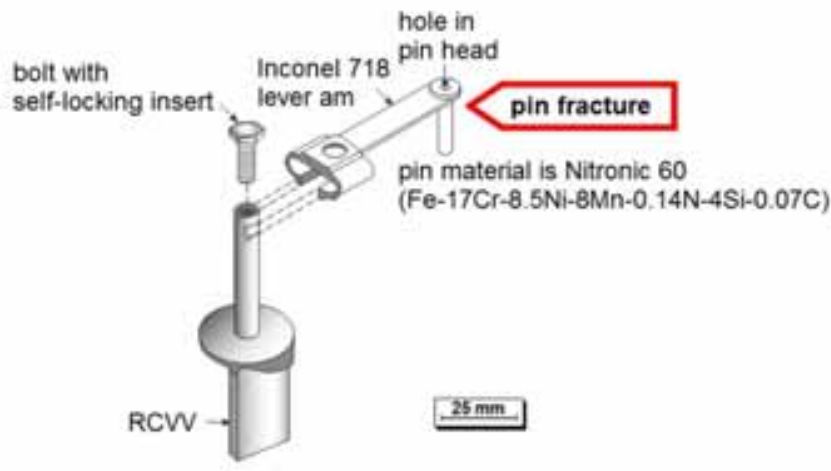

Figure 18. Schematic of RCVV and lever arm assembly, indicating the fracture of the pin attached to the lever arm [6]

The lever arm material was Inconel 718, a nickel-base superalloy. The pin material was Nitronic 60, a stainless steel. Detailed investigation showed that the pin had undergone stress corrosion cracking (SCC).

\section{Causes of failure}

Pin material: The SCC susceptibility of Nitronic 60 was unknown, until identified by the NLR.

Residual stresses: Cold-upsetting the pin head to attach it to the RCVV lever arm resulted in high residual stresses. The combination of these stresses and a concentrated salt solution in the crevice between the lever arm and pin resulted in SCC. Figures 19 and 20 show the pin fracture surface and an evidence of the corrosion and SCC. The actual (physical) cause of the engine failure involved a sequence of events, see Figure 21 [6,9].

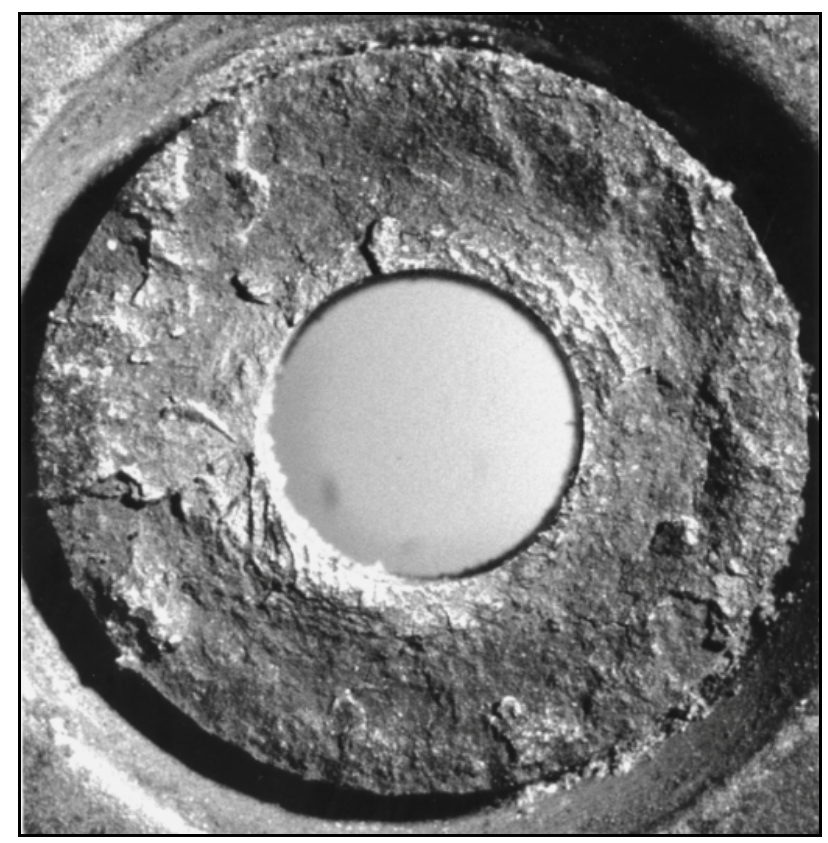

Figure 19. As-received fracture surface of the lever arm pin [6]

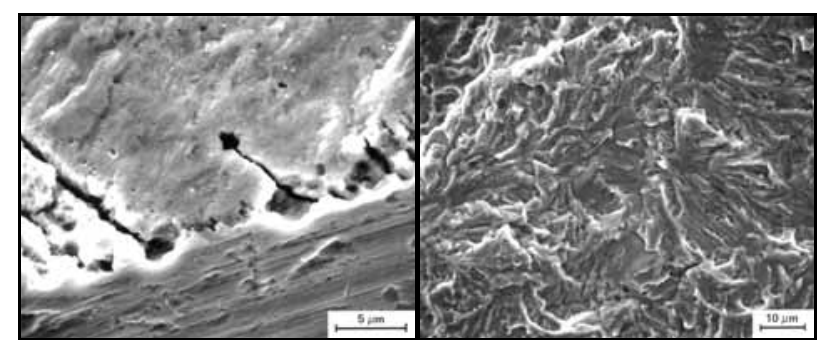

Figure 20. Corrosion and stress corrosion cracking of the lever arm pin (1. corrosion pits and slots running from hole in pin head, 2. transgranular SCC) [6]

1

$$
\begin{aligned}
& \text { salt in by-pass air deposits on lever arms } \\
& \text { and absorbs moisture during shutdowns }
\end{aligned}
$$

2 crevices between arm and pin

$$
\checkmark
$$

3 crevice corrosion, $\mathrm{SCC}$ and the fracture of a pin

$$
7
$$

4

mispositioned $5^{\text {th }}$ stage RCVV

5 aerodynamic excitation of $6^{\text {th }}$ stage compressor blades

$$
\checkmark
$$

6

\section{fatigue failure of the blade-retaining} lugs on $6^{\text {th }}$ stage rotor

\section{$\checkmark$}

7 blade loss and internal disintegration of the engine

Figure 21. Sequence of events leading to the F100-PW-220 engine failure 


\section{Required specialist knowledge}

Investigating the foregoing service failures required a broad range of knowledge and expertise. Fig.22 summaries the specialist knowledge and techniques used.

- The failures cover many classes of aircraft metallic materials: aluminium alloys, high and medium strength low alloy steels, carbon steels, stainless steels, titanium alloys and nickel-base superalloys.

- Fractographic analyses were always needed. Fractography had to identify the fracture mechanisms, including fatigue, stress corrosion and overload, and take account of the environmental effects.

- Metallography was usually needed to aid or confirm the fractographic analyses.

- Chemical analyses were usually done to check on the materials.

\begin{tabular}{|c|c|c|c|c|}
\hline & & S-61N & AT-301 & F-100 \\
\hline \multicolumn{2}{|c|}{ Fractography } & $\bullet$ & $\bullet$ & $\bullet$ \\
\hline \multicolumn{2}{|c|}{ Fracture cleaning } & $\bullet$ & & $\bullet$ \\
\hline \multicolumn{2}{|c|}{ NDI } & & $\bullet$ & \\
\hline \multicolumn{2}{|c|}{ Metallography } & & $\bullet$ & $\bullet$ \\
\hline \multicolumn{2}{|c|}{ Hardness } & & & $\bullet$ \\
\hline \multicolumn{2}{|c|}{ Chemical analysis } & $\bullet$ & $\bullet$ & $\bullet$ \\
\hline \multirow{3}{*}{ Testing } & tensile & $\bullet$ & & $\bullet$ \\
\hline & fatigue & $\bullet$ & & \\
\hline & SCC & $\bullet$ & $\bullet$ & $\bullet$ \\
\hline Fatigue analysis & $\begin{array}{c}\text { crack } \\
\text { growth }\end{array}$ & • & $\bullet$ & \\
\hline \multirow{3}{*}{ Metallurgy } & aluminium & $\bullet$ & $\bullet$ & \\
\hline & steels & & & $\bullet$ \\
\hline & superalloys & & & $\bullet$ \\
\hline
\end{tabular}

Figure 22. Summary of the required specialist knowledge and techniques [6]

\section{Conclusion}

Failure of an aircraft structural component can have catastrophic consequences, with a resultant loss of life and of the aircraft. Any failure occurring on structural materials applied on the air platforms needs to be studied in order to avoid other accidents which are going to happen on an aircraft of the same fleet. Though, the economic and safety issues are driving forces to develop more efficient failure analysis and investigations.

A Failure Investigation is undertaken to determine the cause of the failure, and if possible, to identify corrective actions that should be initiated to prevent similar failures. Failure analysis is a powerful tool for solving engineering problems and can provide significant savings in the development of components. The nature of the failure being investigated determines what steps and processes must be employed.

Investigating the foregoing service failures required a broad range of knowledge and expertise. The failures cover many classes of aircraft metallic materials. Fractographic analyses were always needed. Fractography had to identify the fracture mechanisms, including fatigue, stress corrosion and overload, and take account of the environmental effects. Metallography was usually needed to aid or confirm the fractographic analyses. Chemical analyses were usually done to check on the materials.

\section{References}

[1] S.J FINDLAY,N.D HARRISON, Why aircraft fail, Materials Today, Elsevier, November 2002

[2] NATO Science and Technology Organization, RTO-TR-AVT-137 AC/323(AVT-137)TP/396, Corrosion and Maintenance Data Sharing, Final Report of Task Group AVT-137, November 2011, http://natorto.cbw.pl/uploads/2011/11/\$\$TR-AVT-137-ALL.pdf

[3] http://www.canadoilgroup.com/Quality-Assurance

[4] METSERVE INTERNATIONAL, Fractography, http://www.metserve.co.za/fractography.htm

[5] ENRIQUE ROCHA-RANGEL, Fracture Toughness Determinations by Means of Indentation Fracture, Universidad Politécnica de Victoria, México,

http://www.intechopen.com/books/nanocomposites-with-uniqueproperties-and-applications-in-medicine-and-industry/fracturetoughness-determinations-by-means-of-indentation-fracture

[6] R.J.H. WANHILL, Some notable aircraft service failures investigated by the National Aerospace Laboratory NLR, Report No.NLR-TP-2009-001, National Aerospace Laboratory NLR, Amsterdam, the Netherlands, October 2009

[7] WANHILL, R.J.H., Graaf, E.A.B. de, Vet, W.J. van der, Investigation into the cause of an S-61N helicopter accident, Part I: fractographic analysis and blade material tests, NLR Technical Report NLR TR 74103 C, National Aerospace Laboratory NLR, Amsterdam, the Netherlands, 1974

[8] KOLKMAN, H.J., On the cause of failure of a propeller blade of Air Tractor PH-CPR, NLR Technical Report NLR TR 87086 C, National Aerospace Laboratory NLR, Amsterdam, the Netherlands, 1987

[9] KOOL, G.A., KOLKMAN, H.J., WANHILL, R.J.H., Aircraft accident F16/J-054: F100-PW-220 6th stage disk and $5^{\text {th }}$ stage RCVV pin investigation, NLR Contract Report NLR CR 92424 C, National Aerospace Laboratory NLR, Amsterdam, the Netherlands, 1992

\title{
Istraživanje otkaza: Postupak analize i neki značajniji eksploatacijski otkazi vazduhoplova
}

\begin{abstract}
Otkaz vazduhoplovne strukturne komponente može imati katastrofalne posledice, koje dovode do gubitka života $\mathrm{i}$ vazduhoplova. Istraga otkaza i propusta u strukturi vazduhoplova je, dakle, od vitalnog značaja u sprečavanju daljih incidenata. Ovaj pregled razmatra opšte oblike uočenih otkaza u vazduhopovnim strukturama, sa primerima iz istorije. Takođe, ovaj rad predstavlja istražne procedure koje se primenjuju u istraživanju otkaza. Dat je pregled tri značajna eksploataciona otkaza vazduhoplova i vazduhoplovna motora koji su istraživani u Nacionalnoj vazduhoplovnoj laboratoriji NLR u Holandiji. Sva tri otkaza su inicirana korozijom.
\end{abstract}




\title{
Исследования отказов: Процесс анализа и некоторые важныеэксплуатационные отказы летательных аппаратов
}

\begin{abstract}
Отказ структурных компонент самолёта может иметь катастрофические последствия, что приводит к потере жизни экипажа и самолёта. Расследование аварий, неисправностей и дефектов в конструкции самолёта имеет жизненно важное значение в предотвращении дальнейших инцидентов. В этом обзоре рассматриваются общие формы воспринимаемых отказов в авиационных структурах, с примерами из истории. Кроме того, этот документ представляет следственные процедуры, используемые в исследовании отказов. Здесь дан обзор трёх значащих эксплуатационных отказов воздушных судов и авиационных двигателей, которые расследуются в Национальной аэрокосмической лаборатории NLR в Нидерландах. Все три отказа были инициированы коррозией.
\end{abstract}

Ключевые слова: самолёт, вертолёт, винт, ротор вертолёта, коррозия, отказ, анализ процесса, фрактография

\section{Examen de la défaillance: procédure d'analyse et certaines significatives défaillance de service des aéronefs}

\begin{abstract}
La défaillance de la composante structurale de l'aéronef peut avoir des conséquences catastrophiques capables de causer la perte des vies et des aéronefs. L'examen de la défaillance et des défauts dans la structure de l'aéronef est dons d'importance vitale dans la prévention des futurs incidents. Ce travail considère les formes communes des défaillances constatées chez les structures des aéronefs avec les exemples observés au cours de l'histoire. Dans ce travail on présente aussi les procédures d'examen appliquées durant les examens de la défaillance. On a donné le tableau de trois défaillances importantes chez les aéronefs et chez les moteurs d'aéronefs qui ont été examinés au laboratoire national d'aviation NRL en Hollande. Toutes les trois défaillances examinées ont été causées par la corrosion.
\end{abstract}

Mots clés: avion, hélicoptère, hélice, rotor d'hélicoptère, corrosion, défaillance, analyse de processus, fractographie. 